\title{
POÇOS DE ALTAS VAZÕES NOS AQUIFEROS CRISTALINOS DA GRANDE SÃO PAULO
}

\author{
U.Duarte 1 \\ L.N.Menegasse ${ }^{2}$ \\ J.A.B.Sabadia ${ }^{2}$
}

A crescente demanda de água nas áreas periféricas da RMGSP e a carência cada vez mais pronunciada deste recurso, em boa qualidade, tem levado a Companhia de Saneamento Básico do Estado de São Paulo (SABESP) a optar pela exploração dos aqufferos fraturados de idade pré-cambriana al existentes.

Por meio do convênio entre a SABESP e o Centro de Pesquisas de Águas Subterrâneas (CEPAS), em 1986 (Convênio 032/86 K), foram executados um grande número de estudos hidrogeológicos para locação de poços profundos na RMGSP.

Dentro do contexto geológico regional as rochas pré-cambrianas dos aqufferos fraturados na RMGSP são constituidos de gnaisses graníticos, migmatitos e micaxistos do embasamento cristalino, e de rochas metapeliticas e metapsamiticas intercaladas a metassedimentos químicos e químico-detrfticos cortados por intrusões granfticas (Grupo São Roque).

Vários poços foram perfurados nos terrenos pré-cambrianos a partir dos estudos hidrogeológicos realizados, tendo sido obtidos resultados bastante satisfatórios. Poços com elevadas vazões, consideradas excepcionais dentro do contexto dos aquiferos fraturados, nos quais as vazões dos poços normalmente encontradas situam-se abaixo de $5,0 \mathrm{~m}^{3} / \mathrm{h}$ e a "capacidade especffica" abaixo de $1,0 \mathrm{~m}^{3} /$ h.m.

Serão expressos a seguir os valores das características hidráulicas, vazão e "capacidade especffica" dos seis (06) poços com vazões excepcionais, até água perfurados no

${ }_{1}^{1}$ Departamento de Geologia Econômica e Geofísica Aplicada, Instituto de Geociências, USP.

2Pós-graduação, Departamento de Geologia Econômica e Geofísica Aplicada, Instituto de Geociências, USP. 
contexto litológico local, e os critérios de locação adotados:

1 - Local: Município de Cajamar, bairro Polvilho

Ano de perfuração: 1988

Vazão: $120 \mathrm{~m}^{3} / \mathrm{h}$

Capacidade especifica: $20, \mathrm{~m}^{3} / \mathrm{h} . \mathrm{m}$.

Profundidade: $81,5 \mathrm{~m}$

Litologias: intercalações de filitos e metacalcários com feições cársticas (condutos de dissolução)-Gr.São Roque

Critérios de locação: presença de lineamento tectônico longitudinal (EW) e contato litológico.

2 - Local: Município de Cajamar, bairro Polvilho

Ano de perfuração: 1988

Vazão: $100 \mathrm{~m}^{3} / \mathrm{h}$

Capacidade especffica: $8,4 \mathrm{~m}^{3} / \mathrm{h} . \mathrm{m}$

Profundidade: $42 \mathrm{~m}$

Litologias: intercalações de filitos e metacalcários com condutos de dissolução (Gr.São Roque)

Critérios de locação: presença de lineamento tectônico longitudinal (EW) e contato litológico.

3 - Local: Bairro do Parque Anhanguera (NW do Município de São Paulo)

Ano de perfuração: 1988

Vazão: $142 \mathrm{~m}^{3} / \mathrm{h}$

Capacidade especffica: $10 \mathrm{~m}^{3} / \mathrm{h} \cdot \mathrm{m}$

Profundidade: $98 \mathrm{~m}$

Litologias: intercalações de rochas cálcio-silicáticas e xistos-Gr.São Roque

Critérios de locação: Interseção dos lineamentos tectônicos NE e NW e contato litológico

4 - Local: Bairro Vila Helena - Município de Suzano

Ano de perfuração: 1990

Vazão: $60 \mathrm{~m}^{3} / \mathrm{h}$

Capacidade especffica: $1,94 \mathrm{~m}^{3} /$ h.m.

Profundidade: $123 \mathrm{~m}$ 
Litologias: granitos e xistos do embasamento cristalino critérios de locação: contato litológico entre granitos, xistos e lineamentos estruturais NE.

5 - Local: Bairro Vila Palmeiras - Município de Suzano

Ano de perfuração: 1990

Vazão: $70 \mathrm{~m}^{3} / \mathrm{h}$

Capacidade especffica: $1,65 \mathrm{~m}^{3} / \mathrm{h} . \mathrm{m}$.

Profundidade: $167 \mathrm{~m}$

Litologias: Gnaisses e micaxistos do embasamento cristalino

Critérios de locação: presença de lineamento tetônico NE e contato litológico entre gnaisses e micaxistos.

OBS. Poço surgente

6- Local: Bairro Colônia-Município de S.Paulo

Ano de perfuração: 1989

Vazão: $150 \mathrm{m3} / \mathrm{h}$

Capacidade especifica: $2,91 \mathrm{~m}^{3} / \mathrm{h} / \mathrm{m}$.

Profundidade: $130 \mathrm{~m}$

Litologias: micaxistos do embasamento cristalino

Critérios de locação: Borda da bacia circular internamente constituída de sedimentos argilosos e lineamento tectônico.

OBS. Este poço apresentou condições de artesianismo, com vazão de jorrância de $15 \mathrm{~m}^{3} / \mathrm{h}$ e altura do jorro de 5 metros.

Em todos estes poços as principais entradas d'água são as descontinuidades (fraturas) e contatos litológicos, com exceção apenas dos poços de Polvilho onde o fluxo d'água ocorre nos condutos cársticos (canais de dissolução) dos metacalcários.

Ressalta-se que ótimas vazões (acima de $10 \mathrm{~m}^{3} / \mathrm{m}$ ) também foram obtidas em diversos poços. Porém procurou-se destacar aqui apenas aquelas consideradas excepcionais. Estes resultados mostram claramente a importância de estudos hidrogeológicos prévios de locação para obter-se êxito de produção, utilizando-se fundamentalmente critérios litológicos e estruturais. 